\title{
Drought and flood in the Anthropocene: feedback mechanisms in reservoir operation
}

\author{
Giuliano Di Baldassarre $^{1,2}$, Fabian Martinez ${ }^{1}$, Zahra Kalantari ${ }^{3,4}$, and Alberto Viglione ${ }^{5}$ \\ ${ }^{1}$ Uppsala University, Department of Earth Sciences, 75236 Uppsala, Sweden \\ ${ }^{2}$ Centre for Natural Disaster Science (CNDS), 75236 Uppsala, Sweden \\ ${ }^{3}$ Stockholm University, Department of Physical Geography, 10691 Stockholm, Sweden \\ ${ }^{4}$ Bolin Centre for Climate Research, 10691 Stockholm, Sweden \\ ${ }^{5}$ Vienna University of Technology, Centre for Water Resource Systems, 1040 Vienna, Austria \\ Correspondence to: Giuliano Di Baldassarre (giuliano.dibaldassarre@geo.uu.se)
}

Received: 30 November 2016 - Discussion started: 2 December 2016

Revised: 27 February 2017 - Accepted: 6 March 2017 - Published: 27 March 2017

\begin{abstract}
Over the last few decades, numerous studies have investigated human impacts on drought and flood events, while conversely other studies have explored human responses to hydrological extremes. Yet, there is still little understanding about the dynamics resulting from their interplay, i.e. both impacts and responses. Current quantitative methods therefore can fail to assess future risk dynamics and, as a result, while risk reduction strategies built on these methods often work in the short term, they tend to lead to unintended consequences in the long term. In this paper, we review the puzzles and dynamics resulting from the interplay of society and hydrological extremes, and describe an initial effort to model hydrological extremes in the Anthropocene. In particular, we first discuss the need for a novel approach to explicitly account for human interactions with both drought and flood events, and then present a stylized model simulating the reciprocal effects between hydrological extremes and changing reservoir operation rules. Lastly, we highlight the unprecedented opportunity offered by the current proliferation of big data to unravel the coevolution of hydrological extremes and society across scales and along gradients of social and hydrological conditions.
\end{abstract}

\section{Introduction}

Throughout history, human societies have been severely impacted by hydrological extremes, i.e. drought and flood events. The collapse of various ancient civilizations, for instance, has been attributed to the occurrence of hydrological extremes (e.g. Munoz et al., 2015). Fatalities and economic losses caused by drought and flood events have dramatically increased in many regions of the world over the past decades (Di Baldassarre et al., 2010; Winsemius et al., 2015) and, currently, more than 100 million people per year are affected by hydrological extremes (UN-ISDR, 2016). There is serious concern about future hydrological risk (broadly defined here as a combination of hazard, vulnerability and exposure, e.g. IPCC, 2014) given the potentially negative impact of climatic and socio-economic changes (Hallegatte et al., 2013; Jongman et al., 2014). Thus, it is essential to realistically cap- ture where, how, and why risk will plausibly change in the coming decades and develop appropriate policies to reduce the negative impacts of hydrological extremes, e.g. economic losses and fatalities, while retaining the benefits of hydrological variability, e.g. supporting biodiversity and ecosystem functions.

Human societies have (intentionally or accidentally) altered the frequency, magnitude, and spatial distribution of flood and drought events (Falkenmark and Rockström, 2008; Di Baldassarre et al., 2009; Vörösmarty et al., 2013; Blöschl et al., 2013; Montanari et al., 2013; AghaKouchak et al., 2015; Destouni et al., 2013; Van Loon et al., 2016; Kalantari et al., 2014). Dams and reservoirs are examples of water management measures that deliberately change hydrological variability (Ye et al., 2003) and significantly affect hydrological extremes, as schematically depicted in Fig. 1. 


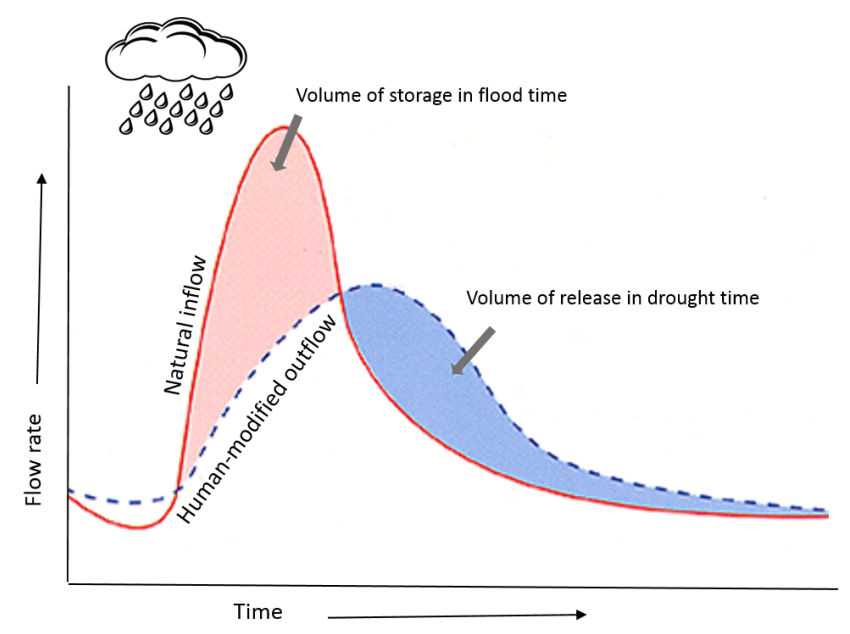

Figure 1. Human impact on hydrological extremes. Schematic example of the impact of dams and reservoirs, which tend to mitigate both hydrological extremes, i.e. lower outflow (blue dashed line) during high-inflow (red line) conditions and higher outflow during low-inflow conditions.

While human societies shape hydrological extremes, hydrological extremes in turn shape human societies. Following the impact of drought or flood events, humans respond and adapt to hydrological extremes through a combination of spontaneous processes and deliberate strategies that can lead to changes in social contracts (Adger et al., 2013). Adaptive responses can take place at the individual, community or institutional level (Myers et al., 2008; Penning-Rowsell et al., 2013). Early warning systems, risk awareness programmes, and changes in land-use planning are examples of adaptive responses that often occur at the local or central government level following hydrological extremes (Pahl-Wostl et al., 2013). Moreover, structural risk reduction measures, such as reservoirs or levees, are also planned, implemented, or revised after the occurrence of drought or flood events, and they in turn (again) change the frequency, magnitude, and spatial distribution of hydrological extremes (Di Baldassarre et al., 2013a).

In the recent decades, natural and engineering scientists have analysed numerous facets of human impacts on drought and flood events, while conversely economists and social scientists have explored human responses to hydrological extremes. Yet, the dynamics resulting from the mutual shaping (i.e. both impacts and responses) of hydrological extremes and societies are still not well understood. As a result, current quantitative methods fail to assess the dynamics of hydrological risk and, while risk reduction strategies built on these methods often work in the short term, they can lead to unintended consequences in the long term. To overcome this lack of knowledge, there has been increasing interest in socio-hydrology in the last few years (e.g. Sivapalan et al., 2012; Srinivasan et al., 2012; Di Baldassarre et al., 2013b; Montanari et al., 2013; Schumann and Nijssen,
2014; Viglione et al., 2014; Elshafey et al., 2014; Van Emmerick et al., 2014; Sivapalan and Bloeschl, 2015; Loucks, 2015; Troy et al., 2015; Gober and Weather, 2015; Pande and Savenije, 2016; Blair and Buytaert, 2016), which aims to develop fundamental science underpinning integrated water resources management (IWRM). Socio-hydrology builds on a long tradition of studies exploring the interplay of nature and society and the implications for sustainability, including political ecology, social-ecological systems, ecologic economics, complex system theories, and research on planetary boundaries (Swyngedouw, 1999; Folke et al., 2005; Liu et al., 2007; Ostrom, 2009; Rockström et al., 2009; Kallis and Norgaard, 2010).

In this context, this paper summarizes the puzzles and dynamics emerging from the interplay of society and hydrological extremes, discusses the need for a novel approach to explicitly account for both drought and flood events, and describes an initial effort to model hydrological extremes in the Anthropocene by means of a stylized model of feedback mechanisms in reservoir operation.

\section{Emerging dynamics and puzzles}

Various dynamics result from the interactions between human societies and hydrological extremes. Learning or adaptation effects emerge when more frequent events are associated with decreasing vulnerability (Di Baldassarre et al., 2015). This effect can be attributed to informal adaptive processes, such as temporary and permanent migration, or changes in policies triggered by the occurrence of hydrological extremes (Pahl-Wostl et al., 2013). For instance, Mechler and Bouwer (2015) showed decreasing flood fatalities in Bangladesh over the past 40 years (Fig. 2a). This reduced vulnerability can be attributed to coping and adaptation capacities gained by individuals or communities after the experience of extreme events. Moreover, Di Baldassarre et al. (2017) showed how the construction of levees protecting flood-prone areas in Rome, Italy, has facilitated increasing floodplain population in the city (Fig. 2b).

Societies are shaped not only by the occurrence of hydrological extremes but also by the perception of current and future risk (Dessai and Sims, 2010). This can explain the emergence of what is termed here as the forgetting or levee effect, i.e. less frequent events associated with increasing vulnerability. Since White (1945), the literature has provided various examples that show that the negative impact of an extreme event tends to be greater if such an event occurs after a long period of calm. Prolonged absence of drought or flood events can be caused by climatic factors (e.g. flood-poor periods; Hall et al., 2014) or the introduction of structural risk reduction measures, such as reservoirs (Fig. 1). One example is the case of Brisbane, where the introduction of a flood retention reservoir in the 1970s shaped risk perception in the local community, which perceived Brisbane as flood-proof 

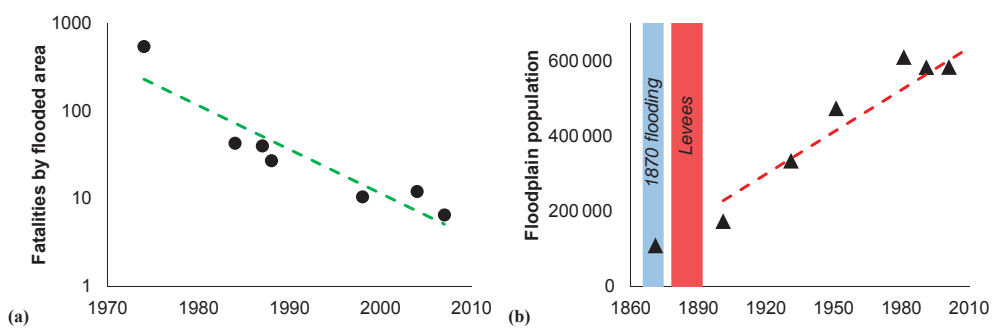

Figure 2. Examples of learning and forgetting effects. (a) Decreasing flood fatalities normalized by flooded area in Bangladesh (data from Mechler and Bouwer, 2015). (b) Increasing population in flood-prone areas in Rome (Italy), following a prolonged absence of flooding due to the construction of levees (data from Ciullo et al., 2016).

until a catastrophic flood event occurred in 2011 (Bohensky and Leitch, 2014).

Learning and forgetting effects have been reported in different parts of the world in a variety of empirical studies, e.g. collection of case studies reported in Di Baldassarre et al. (2015). The emergence of these dynamics suggests the intuitive tendency that the impact of drought or flood events depend on whether their occurrence is expected or not. Yet, these dynamics have mainly been reported as narratives in specific case studies. It is still unclear whether they are exceptional cases or generic mechanisms, and whether they occur randomly or within certain social and hydrological circumstances. This lack of knowledge prevents their explicit inclusion on the analytical tools that undertake a quantitative assessment of hydrological risk.

Besides the inability to capture learning and forgetting dynamics, traditional methods for risk assessment cannot explain interactions between floods, droughts, and water management as they focus on either drought or flood hazard (e.g. Shahid and Behrawan, 2008; Jongman et al., 2014). For instance, while reservoirs theoretically alleviate both flood and drought events (Fig. 1), reservoir operation rules (Mateo et al., 2014) mitigating drought are different from the ones mitigating flood. To cope with drought, reservoirs are typically kept as full as possible, working as a buffer during low-flow conditions, whereas to cope with flood, reservoirs are often kept as empty as possible, allowing the storage of a large quantity of water from extreme rainfall or rapid snowmelt conditions. These reservoir operation rules can change over time depending on various factors, including whether the most recently experienced disaster was caused by a drought or a flood event. As a result, the negative impact of flood events occurring immediately after a long period of drought conditions can be exacerbated.

For example, the aforementioned catastrophic 2011 flooding of Brisbane occurred after an exceptionally long, multiyear drought (the so-called "Millennium Drought"; Van Dijk et al., 2013) which triggered changes in reservoir management (Van den Honert and McAneney, 2011). In particular, operation rules of the flood mitigation reservoir build in 1970s were changed, and the reservoir was used instead as a buffer to cope with drought conditions. This change in operation rules led to higher water levels in the reservoir, which was then less unable to store much water and alleviate the 2011 flood event. Meanwhile, paradoxically, the presence of the reservoir triggered the popular belief that Brisbane was flood-proof and made the population more vulnerable. The combination of these events made the 2011 flooding a major disaster (Bohensky and Leitch, 2014).

Research on climate change suggests that many regions around the world might experience, in the near future, alternate periods with prolonged drought conditions and extreme flood events (IPCC, 2014). The 2017 Oroville Dam crisis in California is one of the most recent disasters generated by high-flow conditions that occur immediately after prolonged droughts. Thus, it is vital to understand whether (and how) human responses to drought might exacerbate the impact of future floods, and vice versa.

Furthermore, a focus on either drought or flood events can limit the interpretation of the role of global drivers of hydrological risk, such as climatic and socio-economic changes. For example, a number of recent studies (e.g. Di Baldassarre et al., 2010; Winsemius et al., 2015) have shown that socioeconomic changes have been the main driver of increasing flood risk in Africa, while climate has (so far) played a smaller role. Yet, by focusing on flood risk alone, these studies did not consider the hypothesis that climate may have led to longer and more severe drought conditions, which in turn have enhanced the need for individuals and communities to move closer to rivers, thus leading to greater exposure to flooding.

Thus, it is still largely unexplored how sequences of drought and flood events make a difference in the dynamics of hydrological risk. This puzzle requires further research on the mutual shaping of human societies and hydrological extremes, to which this paper aims to contribute.

\section{Hydrological extremes in the Anthropocene}

To reveal the aforementioned dynamics resulting from the mutual shaping of hydrological extremes and society, there is a need for both empirical and theoretical research explor- 
ing numerous river basins, floodplains, and cities as coupled human-water systems. Figure 3 schematizes how internal feedback mechanisms within the systems consist of (i) impacts and perceptions of hydrological extremes that shape society in terms of demography, institution, and governance, and (ii) policies and measures implemented by society that shape hydrological extremes in terms of frequency, magnitude, and spatial distribution. These internal dynamics also interact with external drivers of change operating on larger or global scales (Fig. 3), i.e. climatic and human influences outside the system (Turner et al., 2003).

One of the challenges in unravelling the interplay of hydrological extremes and society is the different time and space scales of drought and flood events. While the duration of flood events ranges from hours to days, drought has much longer lifetimes, in the order of weeks, months, or even years. Similarly, spatial scales of flood events are typically smaller than those of drought conditions (Van Loon, 2015). As a result, the integrated effects of these hydrological extremes on society and the associated feedback loops are significantly different. For instance, at the level of crisis management, more time for decision making is available in the case of drought than for flood events. Also, while some flood protection measures can be decided and implemented at the local level within one or few municipalities, drought policies require agreements at regional scales.

Yet, water management policies account for both hydrological extremes. Moreover, for large river basins, the periodicity or clustering of drought and flood events seems to be more coherent in time and space. This is due to mass balance reasons as well as the fact that flood and drought periods are often produced by atmospheric blocking (e.g. Francis and Vavrus, 2012). Lastly, as mentioned in the previous section, the dynamics of human impacts on flood events depend on human responses to drought events, and vice versa. Thus, in the Anthropocene, it is essential to consider both hydrological extremes.

In this context, we present a new model that mimic the interplay between water management and hydrological extremes. This conceptualization builds on similar efforts that were recently made in socio-hydrology (Di Baldassarre et al., 2013b; 2015; Viglione et al., 2014; Kuil et al., 2016), which modelled either drought or flood events but not both hydrological extremes. Our model focuses on the human impact on water storage via reservoirs. As the model aims to explore emerging patterns resulting from generic mechanisms, it was not based on site specific rules of operation or optimization methods. Instead, the model was inspired by the criticism of rational decision making and optimization made by numerous scholars following the work of the Nobel laureate Daniel Kahneman. In particular, Tversky and Kahneman (1973) formulated the availability heuristic as the bias due to the fact that decision makers estimate the probability of events based not only on robust evidence but also "by the ease with which relevant instances come to mind". Tversky

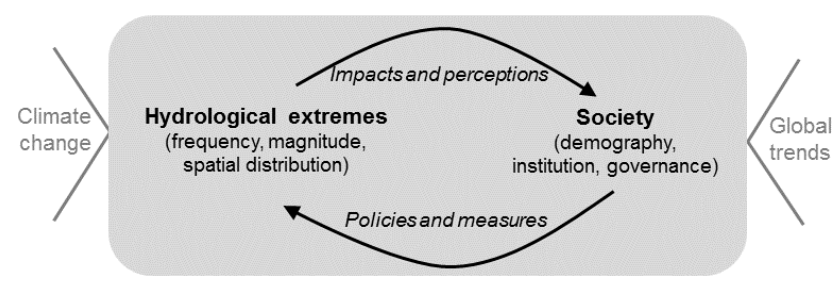

Figure 3. Hydrological extremes in the Anthropocene. Internal feedbacks within the human-water system (grey area, focus of this paper) at the local scale, and external drivers of change that operate at larger/global scale such as climate change and socio-economic trends.

and Kahneman (1973) showed that this judgmental heuristic leads to systematic biases. By extending this concept, we develop a stylized model that simulates the mutual shaping of hydrological extremes and water management.

The model is based on the use of a reservoir, which is used to schematically characterize changes in water storage caused by human activities (Fig. 1). In particular, by considering a time series of natural river discharge $\left(Q_{\mathrm{N}}\right)$ as natural inflow, the human-modified outflow $(Q)$ can be derived from the variation in time of the reservoir storage $(S)$ using a mass balance equation:

$Q=Q_{\mathrm{N}}-\frac{\mathrm{d} S}{\mathrm{~d} t}$.

By assuming a linear reservoir with a storage coefficient $(k)$, the human-modified outflow is related to the reservoir storage by

$Q=\frac{S}{k}$.

To capture the typically high release of water when reservoirs are full, e.g. overflows, we assume that if the storage is above a certain threshold $\left(S_{\max }\right)$, the human-modified outflow will have an additional component which is, for the sake of simplicity, linearly proportional to the difference between $S$ and $S_{\max }$ with an overflow coefficient $(\alpha)$ :

$Q=\frac{S}{k}+\frac{\left(S-S_{\max }\right)}{\alpha}$.

We then use a dynamically changing storage coefficient $(k)$ to explain the changing rules for reservoir operation. This storage coefficient is estimated as a weighted average between a value that allows for enough volume to be available during major flood events $\left(k_{\mathrm{f}}\right)$ and a different value that allows for enough water to be kept in the reservoir and for better coping with drought conditions $\left(k_{\mathrm{d}}\right)$ :

$k=\frac{M_{\mathrm{f}} \cdot k_{\mathrm{f}}+M_{\mathrm{d}} \cdot k_{\mathrm{d}}}{M_{\mathrm{f}}+M_{\mathrm{d}}}$. 
Table 1. Summary of time-varying variables of the stylized model and initial conditions used in the experiment presented here.

\begin{tabular}{lllll}
\hline & Units & Description & Type & $\begin{array}{l}\text { Initial } \\
\text { conditions }\end{array}$ \\
\hline$M_{\mathrm{f}}$ & {$[]$.} & flood memory & state & 1 \\
$M_{\mathrm{d}}$ & {$[]$.} & drought memory & state & 1 \\
$Q$ & {$\left[\mathrm{~L}^{3} \mathrm{~T}^{-1}\right]$} & human-modified outflow & state & $5 \mathrm{~m}^{3} \mathrm{~s}^{-1}$ \\
\hline
\end{tabular}

Table 2. Summary of time invariant parameters of the stylized model and value used in the experiment presented here.

\begin{tabular}{llll}
\hline & Units & Description & Values \\
\hline$k_{\mathrm{f}}$ & {$[\mathrm{T}]$} & storage coefficient to cope with flood & 1.2 years \\
$k_{\mathrm{d}}$ & {$[\mathrm{T}]$} & storage coefficient to cope with drought & 2.5 years \\
$\mu$ & {$[1 / \mathrm{T}]$} & memory decay rate & 0.06 1/year \\
$\alpha$ & {$[\mathrm{T}]$} & overflow coefficient & 10 years \\
$\beta$ & {$[]$.} & bias parameter & 3 \\
$S_{\max }$ & {$\left[\mathrm{L}^{3}\right]$} & maximum reservoir storage & $10^{8} \mathrm{~m}^{3}$ \\
\hline
\end{tabular}

Equation (4) shows that the weights are given by two contrasting memories of the reservoir management system, i.e. flood memory $\left(M_{\mathrm{f}}\right)$ and drought memory $\left(M_{\mathrm{d}}\right)$, which are assumed to change over time depending of actual flow conditions:

$$
\begin{aligned}
\frac{\mathrm{d} M_{\mathrm{f}}}{\mathrm{d} t} & =\mu\left(\frac{Q^{\beta}}{Q_{\mathrm{N}, \text { mean }}^{\beta}}-M_{\mathrm{f}}\right), \\
\frac{\mathrm{d} M_{\mathrm{d}}}{\mathrm{d} t} & =\mu\left(\frac{Q_{\mathrm{N}, \text { mean }}^{\beta}}{Q^{\beta}}-M_{\mathrm{d}}\right) .
\end{aligned}
$$

Equations (5) and (6) formalize our assumption that flood memory is accumulated more than drought memory during high-flow conditions $\left(Q>Q_{\mathrm{N} \text {,mean }}\right)$, while drought memory is accumulated more than flood memory during lowflow conditions $\left(Q<Q_{\mathrm{N} \text {,mean }}\right)$. This assumption is inspired by the aforementioned availability heuristic (Tversky and Kahneman, 1973) and based on the empirical evidence that preparedness tends to be higher immediately after the occurrence of extreme events, which often lead to additional pressure for changes in water management. For example, Hanak (2011) reports the decline in flood insurance coverage in California after the 1997 Central Valley flooding (Fig. 4).

Equations (5) and (6) also describe that both drought and flood memories diminish exponentially over time with a decay rate $\mu$. This assumption is based on previous models of human-flood interactions (Di Baldassarre et al., 2013b, 2015; Viglione et al., 2014; Grames et al., 2016), as well as scientific work on individual and collective memory (Anastasio et al., 2012).

The exponent $\beta$ in Eqs. (3) and (4) is used to characterize the level of bias caused by the difference between drought and flood memories. In particular, for $\beta=0$ both memories

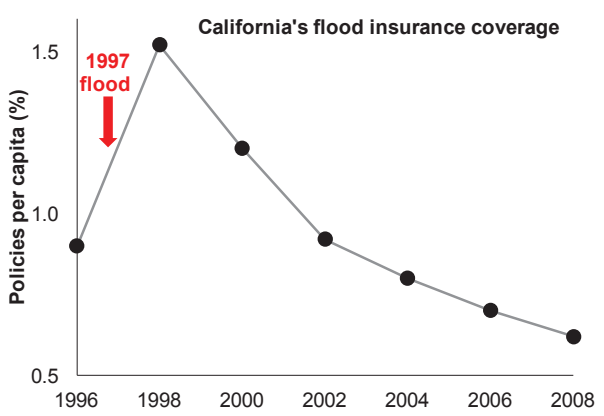

Figure 4. Changing memory and preparedness. Flood insurance coverage in California, which peaked after the 1997 Central Valley flood and then decayed over time (data from Hanak, 2011). Note that in the same period policies per capita in the entire USA were essentially stable (Hanak, 2011).

tend to the value of 1 over time, and $k$ becomes constant. This can be used to describe a rational decision-making system whereby the proportion between $k_{\mathrm{d}}$ and $k_{\mathrm{f}}$ is derived with an optimal design of the reservoir to balance relative weights of drought and flood events. Increasing $\beta$ indicates increasing bias as more dynamic variations of $M_{\mathrm{d}}$ and $M_{\mathrm{f}}$ occur during periods of high- or low-flow conditions, and consequently faster changes in reservoir operation rules. As a summary, Tables 1 and 2 report the state variables and time invariant parameters, respectively, of the stylized model presented here. It is important to note that, as we focus on the feedback mechanisms between flood or drought occurrence and changing reservoir operation rules, this model is highly simplified and does not account for other aspects, including the direct evaporation from the reservoir, the control of overflows (e.g. spillways), and the feedbacks between water supply and demand.

To show an example of the dynamics captured by this model, we compare the results obtained with variable reservoir operation rules, which depend on the changing drought and flood memories, with the results obtained by using fixed storage coefficient to cope with either drought or flood events (Fig. 5). This virtual experiment is run by solving the differential equations numerically with a finite-difference method, and using flow data of the Brisbane River as input, i.e. times series of natural inflow $\left(Q_{\mathrm{N}}\right)$. Given the hypothetical nature of this simulation, parameters and initial conditions are assumed and reported in Tables 1 and 2.

Figure 5a shows the human-modified outflow resulting from changes in operation rules. Shifts in reservoir management are depicted in Fig. 5b in terms of changing values of the storage coefficient using an annual timescale of variability. Figure 5a shows that the 2011 flood event would have had a much lower discharge if the reservoir operations aimed to cope with flood. Yet, prolonged low-flow conditions in the previous decade (i.e. Millennium Drought) led to change in reservoir operations to better cope with drought, 

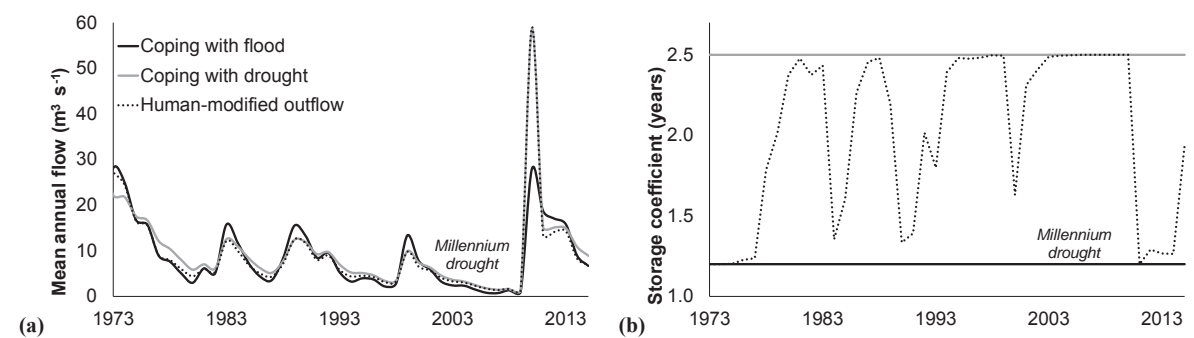

Figure 5. Example of flood after drought. (a) Human-modified outflows (dotted line) that result from changing storage coefficient (b) between the values aiming to cope with flood (black continuous line) and aiming to cope with drought (grey line).
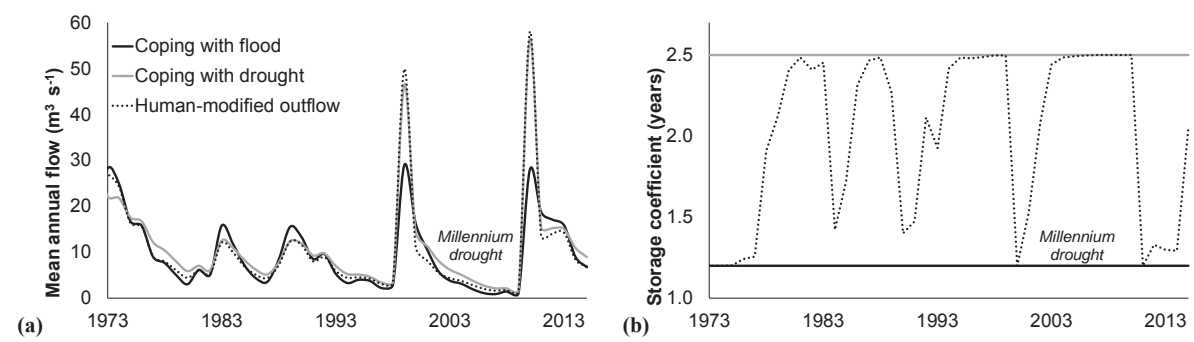

Figure 6. Example of drought after flood. (a) Human-modified outflows (dotted line) that result from changing storage coefficient (b), between the values aiming to cope with flood (black continuous line) and aiming to cope with drought (grey line).

i.e. keep more water in the reservoir instead. This change increased the reservoir storage and led to substantial overflow and therefore an enhancement of 2011 flood outflows. This can be seen as a plausible interpretation of the remarkable severity of the 2011 Brisbane flood disaster.

To complement the above experiment of a flood event occurring shortly after a prolonged drought, we also use the model to explore the impact of a prolonged drought occurring shortly after a flood event. To this end, we make a virtual experiment by assuming the occurrence of exceptionally high flows just before the Millennium Drought (Fig. 6a). The occurrence of this major flood changes operation rules as depicted by Fig. 6b, which shows the changing values of the storage coefficient. This shift made drought conditions more severe, i.e. during the Millennium Drought the humanmodified outflows are lower than the outflows of the "coping with drought" scenario (Fig. 6).

\section{Conclusions and perspectives}

This paper described an initial attempt to study the coevolution of water management and hydrological extremes. This is considered a first step in a broad research agenda that includes both empirical and theoretical work to uncover the mutual shaping of hydrological extremes and society (Fig. 3). In particular, as described by McDonald (1989) and then discussed by Di Baldassarre (2016), the development of new knowledge typically require research efforts that can be classified into five main steps: (1) data collection and analysis; (2) examination of these data to determine salient facts that still need a formal explanation; (3) theory development via formulation of models capturing the salient facts; (4) model calibration, validation and uncertainty analysis; and (5) application of models to support the decision-making process. As discussed by McDonald (1989), some scientists are deeply "engaged in work that refines or makes use of the generally accepted model" (steps 4 and 5), while others are "in the process of questioning the generally accepted model" (steps 1-3). To better understand drought and flood events in the Anthropocene, we believe that research efforts should focus on steps $1-3$, since coevolutionary dynamics are still largely unknown. In particular, to develop socio-hydrological theory, there is a need for iterations between historical analyses of case studies and formal explanations of the salient facts via stylized models, such as the one presented in this paper.

Besides case studies and dynamic models, an unprecedented opportunity to explore coevolutionary dynamics across spatio-temporal scales and socio-hydrological gradients is offered nowadays by the recent proliferation in global remote sensing data and worldwide archives at relatively high spatial (between $100 \mathrm{~m}$ and $5 \mathrm{~km}$ ) and temporal (between 1 day and 1 year) resolution. In particular, useful sources of data from referring to the feedback loop in Fig. 3 are as follows:

- Hydrological extremes: outcomes of global hydrological models; worldwide river flow archives (Hannah et al., 2011); drought and flood inundation maps derived from satellite imagery (Di Baldassarre et al., 2011). 
- Impacts and perceptions: global database of damage caused by droughts and floods (EM-DAT); social media such as Twitter and Facebook.

- Society: global population data and maps of human settlements (Linard and Tatem, 2011); satellite nightlights as proxies for economic growth and human population density (Ceola et al., 2013 ).

- Policies and measures: global maps of land use, irrigation, dams and reservoirs (Bierkens, 2015); information about flood protection standards in different countries (Scussolini et al., 2016).

Two main challenges are associated with the overlay of these different sources of big data: (i) the mismatch in spatial and temporal scales of hydrological and social data and (ii) the need to integrate quantitative data with more qualitative information, e.g. risk perception from Twitter data. This will require the development of new techniques and mixed research methods (Driscoll et al., 2007), allowing a global analysis of these data to reveal whether the emerging dynamics and puzzles described here are either site-specific cases that occur randomly or general patterns that emerge under specific social and hydrological conditions.

Data availability. This study is based on streamflow data of the Brisbane River, Australia. Data were downloaded from the Water Monitoring Information Portal of the Queensland Government, Department of Natural Resources and Mines (DNRM). Link: https://water-monitoring.information.qld.gov.au (last access: 22 March 2017).

Competing interests. The authors declare that they have no conflict of interest.

Acknowledgements. The present work was developed within the framework of the Panta Rhei Research Initiative of the International Association of Hydrological Sciences (IAHS), within the working groups on "Changes in Flood Risk" and "Drought in the Anthropocene". Brisbane river data were downloaded from the Water Monitoring Information Portal of Queensland Government, Department of Natural Resources and Mines (DNRM).

Edited by: M. Sivapalan

Reviewed by: two anonymous referees

\section{References}

Adger, W. N., Quinn, T., Lorenzoni, I., Murphy, C., and Sweeney, J.: Changing social contracts in climate-change adaptation, Nat. Clim. Change, 3, 330-333, 2013.

AghaKouchak, A., Feldman, D., Hoerling, M., Huxman, T., and Lund, J.: Recognizing Anthropogenic Droughts, Nature, 524, 409-411, 2015.
Anastasio, T. J., Ehrenberger, K. A., Watson, P., and Zhang, W.: Individual and collective memory consolidation: Analogous processes on different levels, MIT Press, Cambridge, Massachusetts, 2012.

Bierkens, M. F. P.: Global hydrology 2015: State, trends, and directions, Water Resour. Res., 51, 4923-4947, 2015.

Blair, P. and Buytaert, W.: Socio-hydrological modelling: a review asking "why, what and how?", Hydrol. Earth Syst. Sci., 20, 443478, doi:10.5194/hess-20-443-2016, 2016.

Blöschl, G., Nester, T., Komma, J., Parajka, J., and Perdigão, R. A. P.: The June 2013 flood in the Upper Danube Basin, and comparisons with the 2002, 1954 and 1899 floods, Hydrol. Earth Syst. Sci., 17, 5197-5212, doi:10.5194/hess-17-5197-2013, 2013.

Bohensky, E. and Leitch, A.: Framing the flood: a media analysis of themes of resilience in the 2011 Brisbane flood, Reg. Environ. Change, 14, 475-488, doi:10.1007/s10113-013-0438-2, 2014.

Ceola, S., Laio, F., and Montanari, A.: Satellite night-time lights reveal increasing human exposure to floods worldwide, Geophys. Res. Lett., 41, 7184-7190, 2013.

Ciullo, A., Viglione, A., Castellarin, A., and Di Baldassarre, G.: Socio-hydrological modelling of flood risk dynamics, Hydrolog. Sci. J., doi:10.1080/02626667.2016.1273527, in press, 2016.

Dessai, S. and Sims, C.: Public perception of drought and climate change in southeast England, Environ. Hazards, 9, 340357, 2010.

Destouni, G., Jaramillo, F., and Prieto, C.: Hydroclimatic shifts driven by human water use for food and energy production, Nat. Clim. Change, 3., 213-217, 2013.

Di Baldassarre, G.: Interactive comment on "Moving sociohydrology forward: a synthesis across studies" by T. J. Troy et al., Hydrol. Earth Syst. Sci. Discuss., 12, C1357-C1361, 2016.

Di Baldassarre, G., Castellarin, A., and Brath, A.: Analysis on the effects of levee heightening on flood propagation: some thoughts on the River Po, Hydrolog. Sci. J., 54, 1007-1017, 2009.

Di Baldassarre, G., Montanari, A., Lins, H., Koutsoyiannis, D., Brandimarte, L., and Bloeschl, G.: Flood fatalities in Africa: from diagnosis to mitigation, Geophys. Res. Lett., 37, L22402, doi:10.1029/2010GL045467, 2010.

Di Baldassarre, G., Schumann, G., Brandimarte, L., and Bates, P. D.: Timely low resolution SAR imagery to support floodplain modelling: a case study review, Surv. Geophys., 32, 255-269, 2011.

Di Baldassarre, G., Kooy, M., Kemerink, J. S., and Brandimarte, L.: Towards understanding the dynamic behaviour of floodplains as human-water systems, Hydrol. Earth Syst. Sci., 17, 3235-3244, doi:10.5194/hess-17-3235-2013, $2013 \mathrm{a}$.

Di Baldassarre, G., Viglione, A., Carr, G., Kuil, L., Salinas, J. L., and Blöschl, G.: Socio-hydrology: conceptualising humanflood interactions, Hydrol. Earth Syst. Sci., 17, 3295-3303, doi:10.5194/hess-17-3295-2013, 2013b.

Di Baldassarre, G., Viglione, A., Carr, G., Kuil, L., Yan, K., Brandimarte, L., and Blöschl, G.: Perspectives on socio-hydrology: Capturing feedbacks between physical and social processes, Water Resour. Res., 51, 4770-4781, doi:10.1002/2014WR016416, 2015.

Di Baldassarre, G., Saccà, S., Aronica, G. T., Grimaldi, S., Ciullo, A., and Crisci, M.: Human-flood interactions in Rome over the past 150 years, Adv. Geosci., 44, 9-13, doi:10.5194/adgeo-44-92017, 2017. 
Driscoll, D. L., Appiah-Yeboah, A., Salib, P., and Rupert, D. J.: Merging qualitative and quantitative data in mixed methods research: how to and why not, Ecol. Environ. Anthropol., 3, 19-28, 2007.

Elshafei, Y., Sivapalan, M., Tonts, M., and Hipsey, M. R.: A prototype framework for models of socio-hydrology: identification of key feedback loops and parameterisation approach, Hydrol. Earth Syst. Sci., 18, 2141-2166, doi:10.5194/hess-18-21412014, 2014.

Falkenmark, M. and Rockström, J.: Building resilience to drought in desertification-prone savannahs in Sub-Saharan Africa: The water perspective, Natural Resources Forum, Vol. 32, Blackwell Publishing Ltd, 93-102, http://onlinelibrary. wiley.com/doi/10.1111/j.1477-8947.2008.00177.x/abstract (last access: March 2017), 2008.

Folke, C., Hahn, T., Olsson, P., and Norberg J.: Adaptive governance of social-ecological systems, Annu. Rev. Environ. Resour., 30, 441-473, 2005.

Francis, J. A. and Vavrus, S. J.: Evidence linking Arctic amplification to extreme weather in mid-latitudes, Geophys. Res. Lett., 39, L06801, doi:10.1029/2012GL051000, 2012.

Gober, P. and Wheater, H. S.: Debates-Perspectives on sociohydrology: Modeling flood risk as a public policy problem, Water Resour. Res., 51, 4782-4788, doi:10.1002/2015WR016945, 2015.

Grames, J., Prskawetz, A., Grass, D., Viglione, A., and Blöschl, G.: Modeling the interaction between flooding events and economic growth, Ecol. Econ., 129, 193-209, 2016.

Hall, J., Arheimer, B., Borga, M., Brázdil, R., Claps, P., Kiss, A., Kjeldsen, T. R., Kriaučiūnienė, J., Kundzewicz, Z. W., Lang, M., Llasat, M. C., Macdonald, N., McIntyre, N., Mediero, L., Merz, B., Merz, R., Molnar, P., Montanari, A., Neuhold, C., Parajka, J., Perdigão, R. A. P., Plavcová, L., Rogger, M., Salinas, J. L., Sauquet, E., Schär, C., Szolgay, J., Viglione, A., and Blöschl, G.: Understanding flood regime changes in Europe: a state-of-the-art assessment, Hydrol. Earth Syst. Sci., 18, 27352772, doi:10.5194/hess-18-2735-2014, 2014.

Hallegatte, S., Green, C., Nicholls, R. J., and Corfee-Morlot, J.: Future flood losses in major coastal cities, Nat. Clim. Change, 3, 802-806, 2013.

Hanak, E.: Managing California's water: from conflict to reconciliation, Public Policy Instit. of CA, San Francisco, CA, 2011.

Hannah, D. M., Demuth, S., van Lanen, H. A. J., Looser, L., Prudhomme, C., Rees, G., Stahl, K., and Tallaksen, L. M.: Large-scale river flow archives: importance, current status and future needs, Hydrol. Process., 25, 1191-1200, 2011.

IPCC: Climate Change 2014: Impacts, Adaptation, and Vulnerability, Fifth Assessment Report of the Intergovernmental Panel on Climate Change, Cambridge University Press, Cambridge, 2014.

Jongman, B., Hochrainer-Stigler, S., Feyen, L., Aerts, J. C. J. H., Mechler, R., Wouter Botzen, W. J., Bouwer, L. M., Pflug, G., Rojas, R., and Ward, P. J.: Increasing stress on disaster-risk finance due to large floods, Nat. Clim. Change, 4, 264-268, 2014.

Kalantari, Z., Lyon, S. W., Folkeson, L., French, H. K., Stolte, J., Jansson, P.-E., and Sassner, M.: Quantifying the hydrological impact of simulated changes in land use on peak discharge in a small catchment, Sci. Total Environ., 466-467, 741-754, 2014.

Kallis, G. and Norgaard, R. B.: Coevolutionary ecological economics, Ecol. Econ., 69, 690-699, 2010.
Kuil, L., Carr, G., Viglione, A., Prskawetz, A., and Blöschl, G.: Conceptualizing socio-hydrological drought processes: The case of the Maya collapse, Water Resour. Res., 52, 6222-6242, 2016.

Linard, C. and Tatem, A. J.: Population mapping of poor countries, Nature, 474, 36, 2011.

Liu, J., Dietz, T., Carpenter, S. R., Alberti, M., Folke, C., Moran, E., Pell, A. N., Deadman, P., Kratz, T., Lubchenco, J., Ostrom, E., Ouyang, Z., Provencher, W., Redman, C. L., Schneider, S. H., and Taylor, W. W.: Complexity of Coupled Human and Natural Systems, Science, 317, 1513-1516, 2007.

Loucks, D. P.: Debates-Perspectives on socio-hydrology: Simulating hydrologic-human interactions, Water Resour. Res., 51, 4789-4794, doi:10.1002/2015WR017002, 2015.

Mateo, C. M., Hanasaki, N., Komori, D., Tanaka, K., Kiguchi, M., Champathong, A., Sukhapunnaphan, T., Yamazaki, D., and Oki, T.: Assessing the impacts of reservoir operation to floodplain inundation by combining hydrological, reservoir management, and hydrodynamic models, Water Resour. Res., 50, 7245-7266, 2014.

McDonald, J. F.: Econometric studies of urban population density: a survey, J. Urban Econ., 26, 361-385, 1989.

Mechler, R. and Bouwer, L. M.: Understanding trends and projections of disaster losses and climate change: is vulnerability the missing link?, Climatic Change, 133, 23-35, 2015.

Montanari, A., Young, G., Savenije, H. H. G., Hughes, D., Wagener, T., Ren, L. L., Koutsoyiannis, D., Cudennec, C., Toth, E., Grimaldi, S., Blöschl, G., Sivapalan, M., Beven, K., Gupta, H., Hipsey, M., Schaefli, B., Arheimer, B., Boegh, E., Schymanski, S. J., Di Baldassarre, G., Yu, B., Hubert, P., Huang, Y., Schumann, A., Post, D., Srinivasan, V., Harman, C., Thompson, S., Rogger, M., Viglione, A., McMillan, H., Characklis, G., Pang, Z., and Belyaev, V.: "Panta Rhei - Everything Flows": Change in hydrology and society - The IAHS Scientific Decade 2013-2022, Hydrolog. Sci. J., 6, 1256-1275, doi:10.1080/02626667.2013.809088, 2013.

Munoz, S. E., Gruley, K. E., Massie, A., Fike, D. A., Schroeder, S., and Williams, J. W.: Cahokia's emergence and decline coincided with shifts of flood frequency on the Mississippi River, P. Natl. Acad Sci. USA, 112, 6319-6324, doi:10.1073/pnas.1501904112, 2015.

Myers, C. A., Slack, T., and Singelmann, J.: Social vulnerability and migration in the wake of disaster: the case of Hurricanes Katrina and Rita, Populat. Environ., 29, 271-291, 2008.

Ostrom, E.: A general framework for analysing sustainability of social-ecological systems, Science, 325, 419-422, 2009.

Pahl-Wostl, C., Becker, G., Knieper, C., and Sendzimir, J.: How multilevel societal learning processes facilitate transformative change: a comparative case study analysis on flood management, Ecol. Soc., 18, 58, 2013.

Pande, S. and Savenije, H. H. G.: A sociohydrological model for smallholder farmers in Maharashtra, India, Water Resour. Res., 52, 1923-1947 2016.

Parker, G. A. and Smith, J. M.: Optimality theory in evolutionary biology, Nature, 348, 27-33, 1990.

Penning-Rowsell, E. C., Sultana, P., and Thompson, P. M.: The last resort? Population movement in response to climate-related hazards in Bangladesh, Environ. Sci. Policy, 27, 44-59, 2013.

Rockström, J., Steffen, W., Noone, K., Persson, Å., Chapin, F. S., Lambin, E. F., Lenton, T. M., Scheffer, M., Folke, C., Schellnhu- 
ber, H. J., Nykvist, B., de Wit, C. A., Hughes, T., van der Leeuw, S., Rodhe, H., Sörlin, S., Snyder, P. K., Costanza, R., Svedin, U., Falkenmark, M., Karlberg, L., Corell, R. W., Fabry, V. J., Hansen, J., Walker, B., Liverman, D., Richardson, K., Crutzen, P., and Foley, J. A.: A safe operating space for humanity, Nature, 461, 472-475, doi:10.1038/461472a, 2009.

Schumann, A. and Nijssen, D.: Shortage and surplus of water in the socio-hydrological context, P. Int. Assoc. Hydrolog. Sci., 364, 292-298, doi:10.5194/piahs-364-292-2014, 2014.

Scussolini, P., Aerts, J. C. J. H., Jongman, B., Bouwer, L. M., Winsemius, H. C., de Moel, H., and Ward, P. J.: FLOPROS: an evolving global database of flood protection standards, Nat. Hazards Earth Syst. Sci., 16, 1049-1061, doi:10.5194/nhess-161049-2016, 2016.

Shahid, S. and Behrawan, H.: Drought risk assessment in the western part of Bangladesh, Nat. Hazards, 46, 391-413, 2008.

Sivapalan, M. and Bloeschl G.: Time scale interactions and the coevolution of humans and water, Water Resour. Res., 51, 69887022, 2015.

Sivapalan, M., Savenjie, H. G., and Blöschl, G.: Socio-hydrology: A new science of people and water, Hydrol. Process., 26, 12701276, 2012.

Srinivasan, V., Lambin, E. F., Gorelick, S. M., Thompson, B. H., and Rozelle, S.: The nature and causes of the global water crisis: Syndromes from a meta-analysis of coupled human-water studies, Water Res. Res., 48, W10516, doi:10.1029/2011wr011087, 2012.

Swyngedouw, E.: Modernity and hybridity: nature, regeneracionismo, and the production of the Spanish waterscape, 18901930, Ann. Assoc. Am. Geogr., 89, 443-465, 1999.

Troy, T. J., Konar, M., Srinivasan, V., and Thompson, S.: Moving sociohydrology forward: a synthesis across studies, Hydrol. Earth Syst. Sci., 19, 3667-3679, doi:10.5194/hess-19-36672015, 2015.

Turner, B. L., Kasperson, R. E., Matson, P. A., McCarthy, J. J., Corell, R. W., Christensen, L., Eckley, N., Kasperson, J. X., Luers, A., Martello, M. L., Polsky, C., Pulsipher, A., and Schiller, A.: A framework for vulnerability analysis in sustainability science, P. Natl. Acad. Sci. USA, 100, 8074-8079, 2003.

Tversky, A. and Kahneman, D.: Availability: A heuristic for judging frequency and probability, Cognit. Psychol., 5, 207-232, 1973.

UN-ISDR: Flood and drought disaster statistics collected by the United Nations Office for Disaster Risk Reduction, available at: http://www.preventionweb.net, last access: 20 January 2016.
Van den Honert, R. C. and McAneney, J.: The 2011 Brisbane Floods: Causes, Impacts and Implications, Water, 3, 1149-1173, 2011.

Van Dijk, A. I. J. M., Beck, H. E., Crosbie, R. S., de Jeu, R. A. M., Liu, Y. Y., Podger, G. M., Timbal, B., and Viney, N. R.: The Millennium Drought in southeast Australia (2001-2009): Natural and human causes and implications for water resources, ecosystems, economy, and society, Water Resour. Res., 49, 1040-1057, 2013.

Van Emmerik, T. H. M., Li, Z., Sivapalan, M., Pande, S., Kandasamy, J., Savenije, H. H. G., Chanan, A., and Vigneswaran, S.: Socio-hydrologic modeling to understand and mediate the competition for water between agriculture development and environmental health: Murrumbidgee River Basin, Australia, Hydrol. Earth Syst. Sci., 18, 4239-4259, doi:10.5194/hess-18-42392014, 2014.

Van Loon, A. F.: Hydrological drought explained, WIREs Water, 2, 359-392, 2015.

Van Loon, A. F., Gleeson, T., Clark, J., Van Dijk, A., Stahl, K., Hannaford, J., Di Baldassarre, G., Teuling, A. J., Tallaksen, L. M., Uijlenhoet, R., Hannah, D. M., Sheffield, J., Svoboda, M., Verbeiren, B., Wagener, T., Rangecroft, S., Wanders, N., and Van Lanen, H. A. J.: Drought in the Anthropocene, Nat. Geosci., 9, 8991, 2016

Viglione, A., Di Baldassarre, G., Brandimarte, L., Kuil, L., Carr, G., Salinas, J. L., Scolobig, A., and Blöschl, G.: Insights from socio-hydrology modelling on dealing with flood risk - Roles of collective memory, risk-taking attitude and trust, J. Hydrol., 518, 71-82, doi:10.1016/j.jhydrol.2014.01.018, 2014.

Vörösmarty, C. J., Pahl-Wostl, C., Bunn, S. E., and Lawford, R.: Global water, the Anthropocene and the transformation of a science, Curr. Opin. Environ. Sustain., 5, 539-550, 2013.

White, G. F.: Human Adjustments to Floods, Department of Geography Research Paper no. 29, Department of Geography Research, Chicago, 1945.

Winsemius, H. C., Aerts, J. C. J. H., van Beek, L. P. H., Bierkens, M. F. P., Bouwman, A., Jongman, B., Kwadijk, J. C. J., Ligtvoet, W., Lucas, P. L., van Vuuren, D. P., and Ward, P. J.: Global drivers of future river flood risk, Nat. Clim. Change, 6, 381-385, doi:10.1038/nclimate2893, 2015.

Ye, B., Yang, D., and Kane, D. L.: Changes in Lena River streamflow hydrology: Human impacts versus natural variations, Water Resour. Res., 39, 1200, doi:10.1029/2003WR001991, 2003. 